\title{
Composition, stability, and measurement of reduced uranium phases for groundwater bioremediation at Old Rifle, $\mathrm{CO}$
}

K.M. Campbel1 ${ }^{1, *}$, J.A. Davis ${ }^{1,2}$, J. Bargar ${ }^{3}$, D. Giammar ${ }^{4}$, R. Benier-Latmani ${ }^{5}$, R. Kukkadapu ${ }^{6}$, K.H. Williams ${ }^{2}$, H. Veramani ${ }^{4}$, K-U. Ulrich ${ }^{4,7}$, J. Stubbs ${ }^{3}$, S. Yabusaki ${ }^{6}$, L. Figueroa ${ }^{8}$, E. Lesher $^{8}$, M.J. Wilkins ${ }^{6}$, A. Peacock ${ }^{9}$, P.E. Long ${ }^{6}$

1. * (corresponding author) USGS, 345 Middlefield Road, Menlo Park, CA 94025 and 3215 Marine St, Boulder, CO, 80303; (303) 541-3035; kcampbell@usgs.gov

2. Lawrence Berkeley National Laboratory, 1 cyclotron Rd., MS 90-1116, Berkeley, CA 94720

3. Stanford Synchrotron Radiation Lightsource, 2575 Sand Hill Road, Menlo Park, CA 94025

4. Washington University in Saint Louis, One Brookings Drive, St. Louis, MO 63130

${ }^{5 .}$ Environmental Microbiology Laboratory, École Polytechnique Fédérale de Lausanne, Lausanne, CH 1015, Switzerland

6. Pacific Northwest National Laboratory, Richland, WA 99352

7. BGD Boden- und Grundwasserlabor GmbH Dresden, Tiergartenstraße 48, 01219 Dresden, Germany

${ }^{8}$ Colorado School of Mines, 1500 Illinois St., Golden, CO 80401

${ }^{9}$ Haley and Aldrich, Oak Ridge, TN 37830 


\begin{abstract}
Reductive biostimulation is currently being explored as a possible remediation strategy for uranium (U) contaminated groundwater, and is currently being investigated at a field site in Rifle, CO, USA. The long-term stability of the resulting U(IV) phases is a key component of the overall performance and depends upon a variety of factors, including rate and mechanism of reduction, mineral associations in the subsurface, and propensity for oxidation. To address these factors, several approaches were used to evaluate the redox sensitivity of $U$ : measurement of the rate of oxidative dissolution of biogenic uraninite $\left(\mathrm{UO}_{2(\mathrm{~s})}\right)$ deployed in groundwater at Rifle, characterization of a zone of natural bioreduction exhibiting relevant reduced mineral phases, and laboratory studies of the oxidative capacity of $\mathrm{Fe}(\mathrm{III})$ and reductive capacity of $\mathrm{Fe}(\mathrm{II})$ with regard to $\mathrm{U}(\mathrm{IV})$ and $\mathrm{U}(\mathrm{VI})$, respectively.
\end{abstract}

\title{
1. Introduction
}

The legacy of $U$ ore milling and processing has left many sites, particularly in the western U.S., with impacted groundwater even after extensive reclamation projects. Although the concentrations of $U$ at these sites are substantially lower after the mill tailings are removed and the site is remediated, groundwater concentrations still often exceed the maximum contaminant level required for site closure. Since conventional remediation technologies (e.g., pump and treat) are costly for this type of scenario, alternate remediation strategies are currently being investigated. One promising strategy is reductive bioremediation, where dissolved U(VI) is reduced to relatively insoluble $\mathrm{U}(\mathrm{IV})$ by stimulating a native metal-reducing microbial community with an organic carbon substrate such as ethanol, acetate, or molasses. This process has been shown to significantly decrease dissolved U(VI) concentrations (e.g., Anderson et al. 2003).

Since solid phase U(IV) is the desired product of reductive bioremediation, the long term efficacy of treatment will depend on the stability of these phases. Therefore, it is important to identify the mechanisms of formation, characterize the phases, and assess their stability in the subsurface to oxidation. The objectives of this work are to synthesize the results of several studies evaluating (1) the stability of biogenic uraninite $\left(\mathrm{UO}_{2(\mathrm{~s})}\right)$ deployed in groundwater at Rifle, (2) a zone of natural bioreduction exhibiting similar processes observed in artificially stimulated bioreduction, (3) the possible role of abiotic oxidation of U(IV) by Fe(III) as well as $\mathrm{U}(\mathrm{VI})$ reduction by adsorbed $\mathrm{Fe}(\mathrm{II})$.

\section{Results and Discussion}

2.1. In situ $\mathrm{UO}_{2}$ stability in Rifle groundwater

Nanopartculate biogenic uraninite is a well-characterized product of enzymatic U(VI) reduction by several species of metal-reducing bacteria (e.g., Bargar et al. 2008 and refs therein). Although other forms of U(IV) may be produced during reduction, such as U(IV) adsorbed to biomass and minerals (Bernier-Latmani et al. 2010; Fletcher et al. 2010), biogenic uraninite provides a proxy for various $\mathrm{U}(\mathrm{IV})$ phases and can be used to constrain the upper end of U(IV) 
stability in sediments. Of the possible oxidants in groundwater, dissolved oxygen (DO) is particularly important because it is ubiquitous and may be present in relatively high concentrations in upgradient groundwater. Rates of oxidative dissolution by DO were measured in situ by deploying biogenic uraninite in two wells at the Rifle site with differing DO concentrations using a novel membrane-walled cell (Campbell, et al., 2011a). After 104 days of incubation in the groundwater, approximately $50 \%$ of the uraninite was dissolved with no accumulation of corrosion products. Compared to laboratory-derived rates, rates of dissolution in the field are 50-100 times lower. The presence of biomass in the deployment cell additionally retarded the oxidative dissolution in the field. Molecular diffusion and surface passivation by groundwater solutes are likely to be key processes decreasing oxidation rates in the field.

\subsection{Characterization of zone of natural bioreduction}

Several cores were drilled in a zone of natural bioreduction at the Rifle site in an area that had never been subject to acetate amendment. Sediment samples from a transect of samples ranging from typical Rifle sediments to naturally bioreduced sediments were analyzed to determine $U$ and Fe oxidation state, Fe mineralogy, reduced sulfur (S) phases, solid phase organic carbon content, and microbial community. Solid phase U concentrations were substantially higher (2-10 times) in the naturally bioreduced sediments, with significant amounts of U(IV) present. The U(IV) was found to be in an adsorbed phase, rather than as nanocrystalline uraninite. Elevated concentrations of reduced Fe and $\mathrm{S}$ phases as well as organic carbon were also measured. Biomass was correlated to organic carbon, suggesting that natural bioreduction was stimulated by a zone of increased organic carbon, resulting in Fe, U, and $\mathrm{S}$ reduction. The zone of natural bioreduction appears to be stabilized to oxidation, possibly through maintenance of locally reducing conditions by microbial activity and the presence of redox buffering mineral phases (reduced Fe and S phases) (Campbell et al, 2011b).

\subsection{Chemical Extraction for determination of labile U(VI) and oxidizable U(IV) content in sediment}

In natural sediments where solid phase $U$ concentrations are relatively low, as is the case with Rifle, direct spectroscopic measurement of $U$ oxidation state is often beyond the capability of current technology and/or often not feasible for a large number of samples. Since dissolved inorganic carbon is a strong ligand for $\mathrm{U}(\mathrm{VI})$, bicarbonate/carbonate chemical extractions can serve as an alternate method for measuring solid phase $U$ oxidation state. Anoxic sediment extracted with a bicarbonate/carbonate solution liberates labile (adsorbed) U(VI), while a subset of the same sample extracted under oxic conditions releases total oxidizable/labile U(VI); the difference is the oxidizable U(IV) content of the sediment. Conventionally, the anoxic extraction is performed at $\mathrm{pH} 9.4$ under a $5 \% \mathrm{CO}_{2}$ atmosphere in an anaerobic chamber (Kohler et al. 2004). However, a comparison of oxidation state estimates obtained on a naturally-bioreduced Rifle sediment using the anoxic extraction method and X-ray absorption spectroscopy showed that substantial oxidation of U(IV) occurred during anoxic extraction. Subsequent experiments 
with biogenic uraninite and ferrihydrite and additional thermodynamic calculations demonstrated that $\mathrm{Fe}(\mathrm{III})$ can oxidize U(IV) under anoxic extraction conditions. A new extraction method was shown to prevent anaerobic oxidation in Rifle sediments by increasing the $\mathrm{pH}$ to 10.5 and decreasing the $\mathrm{CO}_{2}$ atmosphere to $400 \mathrm{ppm}$. In addition, the experiments and calculations extend the range of $\mathrm{pH}$ and $\mathrm{CO}_{2}$ conditions reported by Ginder-Vogel and co-workers (Ginder-Vogel et al. 2006), and suggest that $\mathrm{U}(\mathrm{IV})$ oxidation by $\mathrm{Fe}(\mathrm{III})$ is a potentially relevant abiotic process in natural sediments.

\subsection{Abiotic reduction of $\mathrm{U}(\mathrm{VI})$ by $\mathrm{Fe}(\mathrm{II})$}

Although dissolved $\mathrm{Fe}(\mathrm{II})$ is relatively unreactive toward $\mathrm{U}(\mathrm{VI})$ at circumneutral $\mathrm{pH}$, Fe(II) adsorbed to Fe oxides has been shown to reduce adsorbed U(VI) (Liger et al. 1999). Proposed mechanisms of this interaction include direct electron transfer between adsorbed species and/or electron migration through a conductive mineral. To elucidate the former mechanism, $\mathrm{Fe}(\mathrm{II})$ and $\mathrm{U}(\mathrm{VI})$ adsorption onto a non-conductive mineral $\left(0.5 \mathrm{~g} / \mathrm{L} \gamma-\mathrm{Al}_{2} \mathrm{O}_{3}\right)$ was investigated at $\mathrm{pH} 7$ and 8.2 at several different surface loadings and concentrations of $\mathrm{CO}_{2}$ in an anaerobic chamber. To understand the effects of competitive adsorption between $\mathrm{Fe}(\mathrm{II})$ and $\mathrm{U}(\mathrm{VI})$ on surface loading in the system, $\mathrm{Ni}(\mathrm{II})$ was used as a proxy for $\mathrm{Fe}(\mathrm{II})$ in a separate set of adsorption experiments. Ni(II) was also used as a non-reactive control condition. At $\mathrm{pH} 7$, no reaction between $\mathrm{Fe}(\mathrm{II})$ and $\mathrm{U}(\mathrm{VI})$ was observed under any conditions, but reduction of $\mathrm{U}(\mathrm{VI})$ did occur when approximately equal amounts of adsorbed Fe(II) and U(VI) were present on the alumina surface at $\mathrm{pH} 8.2$. This suggests that at appropriate surface loadings and high $\mathrm{pH}$, a direct electron transfer between Fe(II) and U(VI) can occur. This is consistent with an Fe(II) oligomer formation mechanism proposed for this reaction (Boyanov et al. 2007). The results suggest that the direct reaction of adsorbed Fe(II) with adsorbed U(VI) is unlikely to proceed at the $\mathrm{pH}$ of Rifle groundwater.

\section{Conclusions}

With the goal of producing stable, insoluble reduced U(IV) phases, biostimulation is a promising strategy for contaminated groundwater remediation. The stability of products in the field depends upon a variety of factors, including rate and mechanism of reduction, mineral associations in the subsurface, and propensity for oxidation. A zone of natural bioreduction suggests that long-term stability of adsorbed U(IV) phases may be possible, potentially by sustaining locally reduced conditions, precipitating redox-buffering minerals, and even maintaining the presence of biomass. Biogenic uraninite was found to be more stable to oxidation by DO under aquifer conditions than predicted in laboratory studies, and its nanoparticulate nature does not appear to make it more susceptible to oxidation. Kinetic limitations of chemical diffusion may extend the lifetime of U(IV) in the subsurface. However, other oxidants in the subsurface, such as Fe(III) oxides, may be important. Although further research is necessary to determine the redox balance in the field, laboratory results indicate that the favorability of $\mathrm{Fe}(\mathrm{III})$ as an oxidant over $\mathrm{Fe}(\mathrm{II})$ as a reductant is very sensitive to 
geochemical conditions, and may be an important consideration during and after active remediation.

\section{Acknowledgments}

This material is based upon work equally supported through the Integrated Field Research Challenge Site (IFRC) at Rifle, Colorado and the Lawrence Berkeley National Laboratory's Sustainable Systems Scientific Focus Area. The U.S. Department of Energy (DOE), Office of Science, Office of Biological and Environmental Research funded the work under contract DE-AC02-05CH11231 (Lawrence Berkeley National Laboratory; operated by the University of California).

\section{References}

Anderson, R. T., H. A. Vrionis, I. Ortiz-Bernad, C. T. Resch, P. E. Long, R. Dayvault, K. Karp, S. Marutzky, D. R. Metzler, A. Peacock, D. C. White, M. Lowe and D. R. Lovley, 2003. Stimulating the in situ activity of Geobacter species to remove uranium from the groundwater of a uraniumcontaminated aquifer. Applied and Environmental Microbiology 69(10), 5884-5891.

Bargar, J. R., R. Bernier-Latmani, D. E. Giammar and B. M. Tebo, 2008. Biogenic Uraninite Nanoparticles and Their Importance for Uranium Remediation. Elements 4(6), 407-412.

Bernier-Latmani, R., H. Veeramani, E. D. Vecchia, P. Junier, J. S. Lezama-Pacheco, E. Suvorova, J. O. Sharp, N. S. Wigginton and J. R. Bargar, 2010. Non-uraninite products of microbial U(VI) reduction. Environmental Science \& Technology xx(xx), xx.

Boyanov, M. I., E. J. O'Loughlin, E. E. Roden, J. B. Fein and K. M. Kemner, 2007. Adsorption of Fe(II) and U(VI) to carboxyl-functionalized microspheres: The influence of speciation on uranyl reduction studied by titration and XAFS. Geochimica Et Cosmochimica Acta 71(8), 1898-1912.

Campbell, K.M., H. Veeramani, K.U. Ulrich, L. Blue, D. Giammar, R. Bernier-Latmani, J.E. Stubbs, E. Surorova, S. Yabusaki, A. Mehta, P.E. Long, and J.R. Bargar, 2011a. Rates and Mechanisms of oxidative dissolution of biogenic uraninite in groundwater at Old Rifle, $\mathrm{CO}$. In Review.

Campbell, K.M, R.K. Kukkapdapu, J.A. Davis , A.D. Peacock, E. Lesher, L. Figueroa, J. Ranville, K.H. Williams, M.J. Wilkins, C.T. Resch, J.P. Icenhower, P.E. Long, 2011 b. Characterizing the extent and role of natural subsurface bioreduction in a uranium-contaminated aquifer. In Preparation.

Fletcher, K. E., M. I. Boyanov, S. H. Thomas, Q. Wu, K. M. Kemner and F. E. Löffler, 2010. U(VI) reduction to mononuclear U(IV) by desulfitobacterium species. Environmental Science and Technology 44(12), 4705-4709.

Ginder-Vogel, M., C. S. Criddle and S. Fendorf, 2006. Thermodynamic constraints on the oxidation of biogenic $\mathrm{UO}<$ sub $>2</$ sub $>$ by Fe(III) (Hydr)oxides. Environmental Science and Technology 40(11), 3544-3550.

Kohler, M., G. P. Curtis, D. E. Meece and J. A. Davis, 2004. Methods for Estimating Adsorbed Uranium(VI) and Distribution Coefficients of Contaminated Sediments. Environmental Science and Technology 38(1), 240-247.

Liger, E., L. Charlet and P. Van Cappellen, 1999. Surface catalysis of uranium(VI) reduction by iron(II). Geochimica Et Cosmochimica Acta 63(19-20), 2939-2955. 


\section{DISCLAIMER}

This document was prepared as an account of work sponsored by the United States Government. While this document is believed to contain correct information, neither the United States Government nor any agency thereof, nor The Regents of the University of California, nor any of their employees, makes any warranty, express or implied, or assumes any legal responsibility for the accuracy, completeness, or usefulness of any information, apparatus, product, or process disclosed, or represents that its use would not infringe privately owned rights. Reference herein to any specific commercial product, process, or service by its trade name, trademark, manufacturer, or otherwise, does not necessarily constitute or imply its endorsement, recommendation, or favoring by the United States Government or any agency thereof, or The Regents of the University of California. The views and opinions of authors expressed herein do not necessarily state or reflect those of the United States Government or any agency thereof or The Regents of the University of California.

Ernest Orlando Lawrence Berkeley National Laboratory is an equal opportunity employer. 